Biljana Stankov ${ }^{1}$, Jasmina Markov², Ivana Milošević ${ }^{3}$ ${ }^{1}$ Higher School of Professional Business Studies in Novi Sad, Serbia

${ }^{2}$ Faculty of Economics in Subotica, Serbia

${ }^{3}$ Faculty of Economics and Engineering Management in Novi Sad, Serbia

\title{
FDI by Economic Activities and Investment Incentives in Bulgaria and Serbia
}

\author{
UDC: $339.727 .22(497.11)$ \\ 330.341 .2 \\ DOI: 10.7595/management.fon.2015.0026
}

\begin{abstract}
Since 2007, when Bulgaria became a full member of the EU and 2012, when Serbia was granted the status of candidate for EU membership, these countries have become very attractive investment destinations. The object of this research is the movements of FDI in the mentioned countries in 2013 and their structure by economic activities. The scientific problem is related to the positive effects of FDI on the host country, making an attractive investment environment, creating incentives for foreign investors and comparing the structure of FDI in Bulgaria and Serbia with simultaneous comparison with the European average. It may be noted that this is a current theoretical and empirical research that deals with modern state of the subject. The necessary quantitative data have been collected using the desk method and using the secondary data source and the method of description as well as the comparative method were used in the ensuing analysis. The aim of the study is to, by applying the above methods, determine the most attractive investment areas, analyze the current investment incentives and provide recommendations on adjustments to be made to improve the actual investment strategies and create attractive investment locations in Bulgaria and Serbia
\end{abstract}

Keywords: FDI, Economic activities, Investors, Investment destination, Investment incentives, Investment location

\section{Introduction}

A long time ago, the United Nations took the view that FDI are such investments that involve agreement of partners, providing long term interests and implementation of control by the company from one country over the company which is a resident of another country. In this way, the company that invests acquires ownership control over the company into which it invests its capital, and which is located in another country outside of its homeland. Especially in recent decades, FDls have become a very attractive form of investing funds, since they provide multiple benefits for both investors and host countries. The experiences of a large number of transition countries, such as Bulgaria and Serbia, have shown that FDls are a more favourable form of inflow of necessary accumulation, compared to conventional loans in the international financial market. The direct inflow of foreign capital improves their economic situation, encourages economic activities, increases employment and productivity, increases exports and stimulates economic recovery. FDI should accelerate the process of economic and political transformation and, as Kragulj (2003) emphasizes, should be a promoter of economic growth and development in countries in transition. However, the real facts cannot be ignored because they show that FDI often cause uncontrolled exploitation of domestic, especially non-renewable resources, influence the growth of unemployment and the creation of technological dependence on foreign companies and sometimes form a model of consumption that generally does not correspond to the level of development of the host country. Countries in transition have occasionally expressed serious dissatisfaction with the economic, social and political impacts of FDI (Vojinović Jaćimović, 2002). It is important to properly assess whether a certain investment will have more beneficial rather than harmful effects, and to make the final decision on that ground. Even so, the above mentioned is a privilege that is available to developed countries, because poorly developed countries in transition, in pursuit of intense economic growth, often accept all foreign investors without taking into account the coming consequences. The predominantly low level of domestic accumulation of capital and the pursuit of dynamic economic growth and development of the economy cause the need for intensification of FDI inflows. Alfaro, Chanda, Kalemli-Ozcan \& Sayek (2004) noticed that the past decade was marked by the increasing role of FDI in total capital flows. In 1998, FDI accounted for more than half of all private capital flows to developing countries. After initial skepticism, as Grandov, Mitic \& 
Vojvodić (2011) found that in the mid-nineties, transient European countries began to compete mutually by creating a more desirable investment ambience in order to attract greater amounts of FDI. According to Cheng \& Kwan (2000) many countries see attracting FDI as an important element in their strategy for economic development because FDI is widely regarded as an amalgamation of capital, technology, marketing and management. They emphasized that an important question for policy makers was what the factors that attract FDI are.

In order to attract foreign investors Bulgaria and Serbia must establish political stability, implement fair processes of privatization, and minimize commercial risk. Some of the incentives which they apply in attracting foreign investors are friendly laws on FDI, reduction of corporate profit tax, elimination of trade barriers and investment prohibitions, financial incentives, low rates of VAT and income tax, low costs of hiring and firing employees and many others. More intensive investments in the Balkan countries started in 2000 and FDI inflows have been growing continuously since, but has in recent years been under a threat due to economic and financial instability in the world. The above said has been confirmed by Penev \& Marušić (2011) who found that, after the period of intensive growth of the inflow of FDI, in 2008, all countries of the region experienced a decrease in direct investments, primarily due to the impact of global economic crisis. Already in 2009 , the inputs of FDI in Bulgaria dropped by more than US $\$ 6000$ million, and in Serbia by nearly US\$1000 million, compared to the trends in the preceding year. In 2012, these countries were referred to as very interesting investment destinations, leading among the SEE countries by attracting production-oriented FDI and job creating.

According to Ernst \& Young's (EYs) Attractiveness Survey (2013), by the realization of 78 investment projects along with securing 10302 new jobs in 2012, Serbia placed itself among the top ten European investment destinations by job creation. In the same year, in Bulgaria, foreign investors encouraged hiring of 4379 new workers, mainly in manufacturing.the following year, even 12179 new jobs were secured in Serbia as a result of the FDI inflows, which accounted for $7 \%$ of all new jobs created in the European countries. In Bulgaria, this number increased slightly to 5505 new jobs. In 2014, in Serbia, there was a significant reduction in this number since 5104 jobs were opened, and participation decreased to $3 \%$, while Bulgaria maintained a constancy of above $3 \%$ share (5688 jobs) in the total number of new working places opened thanks to FDI inflows into European countries. Like many authors, Jensen (2003) concluded that FDI is an important element of the global economy and a central component of economic development strategies of both developed and developing countries. Supporting the previous, Noorbakhsh, Paloni \& Youssef (2001) added that FDls are not only a source of finance and employment but, for developing country governments, they can also be a medium for acquiring skills, technology, organizational and managerial practices and access to markets.

\section{Literature review}

In this research, the opinions of many respected scientists dealing with various issues related to FDI are accepted and relevant literature is used. The research also highlights the similarities in the definition of FDIs, current trends in their development as well as the impact of globalization on FDI inflows. Different views on the impact of FDIs on the host country are mentioned, as well as the factors that affect the investment decision making by foreign investors and decisions on the choice of investment location.

Many definitions of FDI can be found in literature, but they are generally based on conventional elements which read: FDI is a form of international inter-firm cooperation that involves a significant equity stake in or effective management control of host country enterprises. A large number of authors dealing with various issues related to FDI emphasize the increase in their importance, especially in the era of global economy. This is confirmed by Hallward-Driemeier (2003) who says that FDIs have surged dramatically over the last two decades and more developing countries are competing to host these multinationals. As Stein \& Daude (2001) found, one of the most notorious features of the trend toward globalization in recent times has been an increased importance of FDI around the world. The impact of globalization is also mentioned by Zeković (2002) who in his work dealt with globalization and a more recent tendency in the development of economic activities as factors that actuated a strategic allocation of capital and different models of FDI.

FDI will go to countries that pay a higher return on capital, but as Asiedu (2002) points out, finding an appropriate measure for the return on investment is problematic, especially for developing countries. This is because most developing countries do not have well-functioning capital markets and therefore it is difficult to measure the return on capital. Markusen \& Venables (1999) are just some of the authors who have concluded that, over the past two decades, direct investments by multinational firms have grown significantly 
faster than trade flows. FDIs by MNCs have recently grown without precedent and Kugler (2006) noticed that they especially penetrated middle-income countries such as Bulgaria and Serbia. He also mentioned that during the 1990s the growth of FDI flows trebled the growth in international trade.

The impact of FDI on the host economy is a very common topic of many scientific studies and Gligorova (2007) says, in relation to this impact, that it can be recognized in any one of three ways: (1) by stimulating development in the country through GDP growth, export capacity growth and capital stock growth; (2) by improving technical and know-how transfer in the host country; (3) by developing infrastructure that is consistent with environmental standards. The positive impact of FDI is noted by Aitken, Hanson \& Harrison (1997) who found that multinationals which export their goods to foreign markets may induce domestic firms to follow suit, thus acting as "catalysts" for domestic exporters. Taking into account that the analyzed countries are currently struggling with the consequences of the global crisis, it is important to emphasize that FDI is the most desirable form of capital inflows to emerging and developing countries, and, as Busse \& Hefeker (2007) say, it is because those countries are less susceptible to crises. FDI brings the potential for the development of new inputs, or the increase in the quality of the existing ones, which may be possible due to the demand created by the foreign investment, but as RodriguezClare (19996) noticed, it may become available for domestic firms as well. The extraction and distribution of raw materials produced in the host country may be facilitated by improving the network of transport and communication and Bengoa \& Sanchez-Robles (2003) showed that this is possible thanks to FDI inflows. FDI could also add up to economic growth simply by augmenting capital accumulation in the host country. This would require, as Borensztein, De Gregorio \& Lee (1998) highlighted, that FDI should not 'crowd out' equal amounts of investment from domestic sources by competing in product markets or $\square$ nancial markets (for example, under conditions of $\square$ nancial repression). In addition, FDls could increase economic growth if they were more productive, or efficient, than domestic investments. New growth theories suggest that international transfers of technology and knowledge through FDI may affect the performance of host economies (Barrell \& Pain, 1999).

Host country policies can influence FDI flows and as Gastanaga, Nugent and Pashamova (1998) found, this is possible primarily through their influence on the advantages of location in the host country. FDls are seeking quality domestic institutions. According to Yin-Li Tun, Azman-Saini \& Siong-Hook Law (2012), this is because a good institution is able to create better environments for investors especially in terms of lower cost of doing business, lower uncertainty and higher productivity prospect. Asiedu (2002) found that good infrastructure increases the productivity of investments and therefore stimulates FDI flows. Good infrastructure is a necessary condition for foreign investors to operate successfully, regardless of the type of FDI. Investment decisions in emerging markets are also influenced by economic and political risks, confirmed Campos and Kinoshita (2003). Successful implementation of economic reform by the host government is a good signal to investors, as a stable macroeconomic environment implies less investment risk. Countries that want to attract foreign investors, as Stein and Daude (2001) suggested, must strive to improve the quality of their institutions, because that is a strategy which, in addition, should generate other positive externalities.

Some authors, such as Kaufmann, Kraay and Zoido-Lobaton (1999), talk about institutional variables as variables that influence the investment decision making and in that group they count regulatory burden, voice and accountability, government effectiveness, political instability, graft and rule of law. As far as attracting FDI is concerned, Benassy-Quere, Fontagne \& Lahreche-Revil (2001) emphasize that both the level and the volatility of the exchange rate have to be taken into account, since they affect FDI. There are many authors who deal with the impact of corruption on FDI inflows including Busse \& Hefeker (2007), who argue that lower corruption and nationalization risk levels as well as better contract enforcement are associated with higher FDI inflows. Exploring several factors that influence FDI inflows, Globerman \& Shapiro (2002) conclude that, in addition to governance infrastructure as infrastructure that can contribute to economic well-being and create a favorable climate for FDI, physical infrastructure and the environment are also very important.

\section{Methodology}

The quantitative data, necessary for the research, have been collected using the desk method secondary data source „The Investment Map Database”. This database collects yearly FDI statistics for about 200 countries and a detailed FDI sectoral and country breakdown for about 115 countries. In analyzing the data, we have applied the method of description to describe the essential facts related to FDIs, their distribution by economic activities as well as investment incentives offered by analyzed countries. In the further course of the research we have used the comparative method and performed the comparison of the same elements, 
similarities and differences in the trends and structure of FDI in Bulgaria and Serbia, with simultaneous comparison with the European average. The results of this research may be useful to scientific workers whose object of interest is also FDI, to students as a supplement to the existing knowledge in the field of international economics as well as to government agencies that work to improve the investment attractiveness of the studied countries, attracting foreign investors and directing FDI to certain economic sectors.

\section{Results and discussion}

Since the year 2000 Bulgaria has become one of the most attractive investment locations in the Balkans, which has expressly been pointed out after 2007, when it joined the EU. Buch \& Piazolo (2001) find that a cumulative result of (1) projected GDP growth rates, (2) the lack of exposure to the direct impact of the defaulting market instruments, as well as (3) the EU experience that a new member's accession is often followed on by a period of strong economic growth.

Bulgaria has attracted investors by macroeconomic and financial stability, strategic geographical position, educated and specialized workforce, infrastructural subsidies for large investors and various support programs by the Government for priority investment projects as well as by peaceful political situation. Many scientists note that the distribution of FDI depends on both economic and political determinants. Schneier \& Frey (1985) have long ago concluded that a country in which there was political unrest or in which there was a threat of having the investment nationalized was more of a risk and therefore ceterus paribus less attractive to invest in than a country offering political stability and a guarantee of property rights.

The competitive rate of corporate tax of only $10 \%$ in Bulgaria has a stimulating effect on the investors and encourages them to go beyond the existing investments and to commence new investment ventures. In 2013, as presented in Figure 1, the majority of investment projects, $76 \%$, were realized in the area of manufacturing, electricity, gas and steam supply, mining and quarrying, transport, storage and communication. The Bulgarian economy has so far mostly experienced investments from Germany (Aurubis, Liebherr, Schneider Electric and Siemens), Greece (Hellenic Petroleum, OTE and Viohalco), Austria (EVN and Palfinger), Belgium (Melexis and Solvay), Spain (Roca and Keros), the USA (Hewlett Packard and Johnson Controls), Switzerland (Nestle), the United Kingdom (Shell), Sweden (SKF) and Italy (Unicredito). In comparison witho other countries of the region, it may be concluded that Bulgaria has fewer restrictions on foreign ownership. For example, as a member of the EU, it is constantly harmonizing its legislation with the EU legislation, which results in the entry of foreign ownership in many sectors of the economy, so that there are currently no restrictions on foreign ownership in $31,33 \%$ of economic sectors, as measured by the Investing Across Sectors indicators.
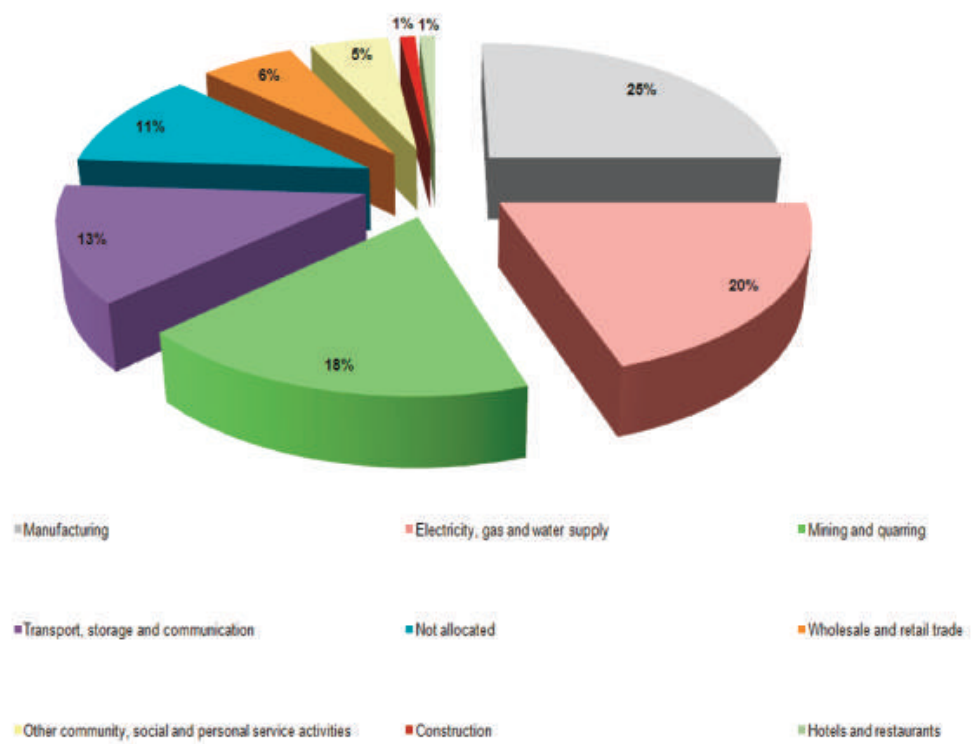

Figure 1: FDI by economic activities in Bulgaria in 2013

Serbia has long been a completely unattractive investment destination, avoided by the Western investors, es- 
pecially in the period of frequent political turmoil. According to Carstensen \& Toubal (2004), besides the quality of the business environment, the overall political climate is also likely to influence FDI. More significant investments in the Serbian economy began only after 2000 when the political situation stabilized, the democratic system of government got promoted, the privatization of the state sector commenced, and the conditions for rapid economic recovery were created. Democratic political systems attract higher levels of FDI inflows both across countries and within countries over time and democratic countries are predicted to attract as much as 70 percent more FDI than their authoritarian counterparts (Jensen, 2003). Researching the same, Li \& Resnick (2003) concluded that if democratic governance hurts a country's attractiveness to foreign investors, the developing country faces a trade-off between competing for limited FDI and democratization.

In the period between 2005 and 2012, the majority of foreign investments in Serbia arrived from Austria, followed by Norway, Germany, Luxembourg, Greece, the Netherlands, Italy, the Russian Federation, Slovenia and Hungary. The companies that have so far invested the most funds in the Serbian economy are Telenor, Fiat Automobili Serbia, Stada-Hemofarm, Philip Morris DIN, Eurobank EFG, Salford Investment Fund, CEE/BIG shopping centers, National Bank of Greece, US Steel, Fondiaria SAI, Pepsi Co Marbo and British American Tobacco South East Europe. It can be seen in Figure 2 that, in 2013, foreign investors mostly invested in manufacturing, then wholesale and retail trade, financial intermediation and construction. As much as $71 \%$ of FDI projects were realized in these economic sectors.
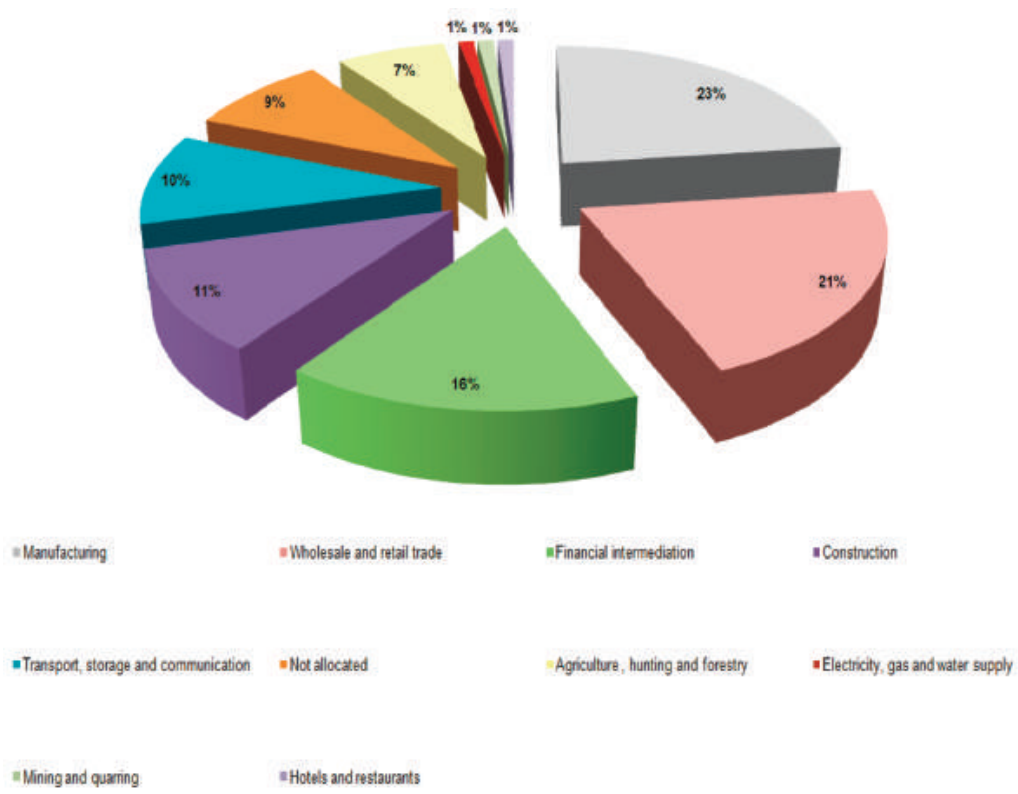

Figure 2: FDI by economic activities in Serbia in 2013

In order to encourage foreign investors to hire additional workers and their recruitment from the local population, Serbia has been applying an income tax rate of only $10 \%$, which is the lowest among neighboring countries. According to Slović (2012), taking into account tax incentives for investments, as well as any other tax benefits, Serbia should, at this moment, from the aspect of tax treatment of foreign investments, represent one of the most attractive investment locations in the region. However, tax incentives as a factor of attraction of FDI come into play only after a favorable investment climate has been created, as observed from the standpoint of other (non-tax) factors. The fact that in 2012 Serbia became a candidate for membership in the EU has stimulated and encouraged many foreign investors to decisively and more confidently approach to investing their funds. EU announcements about potential accession have significant independent effects on FDI flows to countries in transition by increasing FDI to countries whose likelihood of accession is enhanced (Bevan \& Estrin, 2004). 


\section{Conslusion}

In recent years, the interests of foreign investors in Bulgaria and Serbia as investment destinations have been growing, primarily due to the creation of an attractive investment environment and getting closer to the EU. Carstensen \& Toubal (2004) conclude that the last decade has seen a remarkable growth of European but also US outward direct investments in transition countries in Europe. This growth is often regarded as being driven by the process of integration of these countries into the EU and the associated elimination of the barriers to FDI and acceleration of the transition process of those economies. Among other things, Bulgaria has encouraged FDI inflow by applying low rates of corporate income tax, while Serbia does so through the rate of income tax which is the lowest in the region. In order to set up a business company in Bulgaria, foreign investors must devote at least 20 days and undertake about 5 different procedures. In Serbia, it is necessary to devote 14 days while undertaking 8 procedures, which is faster than the European average. In recent years, the largest investors in both countries have been European companies, reaching as much as $90 \%$ in Serbia.

It is necessary to mention that FDI have also forced an increasing number of domestic manufacturers to compete globally (Chen \& Zhang, 1995). In 2012 as well as in 2013, it was manufacturing that was the most attractive area of investment into the analyzed countries. According to the data of EY's Attractiveness Survey, a similar trend was recorded in other European countries where, in 2012, 973 FDI projects were implemented in manufacturing and 101535 new jobs were provided, which amounts to nearly $60 \%$ of all jobs emerging as a result of FDI. It is believed that manufacturing is one of the most attractive economic sectors to foreign investors which is going to attract the most investors in Europe in the coming years (according to some research, $32 \%$ of all investment projects will be carried out in this area). Wholesale and retail trades are a very interesting sector for foreign investors in Serbia with the share in total FDI projects of $11 \%$ in 2012 which increased to $21 \%$ in 2013. According to the European average in the area of trade, in 2012, 1945 FDI projects were implemented, which is significantly more than in the area of manufacturing, but at the same time far fewer jobs were provided (19403-11\% of the total number of new jobs). Taking into account all of the industries invested in, it may be noted that in 2013 in Bulgaria foreign investors have provided 5505, and in Serbia even 12179 new jobs, which places Serbia among the top ten most successful European countries. It is important to emphasize that FDI can raise the quality of domestic human capital and improve the know-how and managerial skills of local firms (Bengoa \& Sanchez-Robles, 2003). When talking about human capital, Branstetter (2006) found that FDI is an alternate, potentially equally important channel for the mediation of knowledge spillovers.

By analyzing factors that disrupt business activities in Bulgaria and Serbia, which hinder foreign investors in making investment decisions, it is asserted that one of the leading factors is corruption. According to Habib \& Zurawicki (2002) foreign investors generally avoid corruption because it is considered wrong and it can create operational inefficiencies. EYs attractiveness survey (2015) says that the biggest threats to attractiveness, among the ten analyzed of all European countries as destinations for foreign investments are too much bureaucracy, low economic growth and lack of political governance at the EU level. These factors account for half of all threats. Even $46 \%$ of nearly a thousand foreign investors who were surveyed said that they want stability and transparency of political, legal and regulatory framework and $48 \%$ of them proposed to implement business-friendly reforms in host countries especially within the areas of competition, tax and labor market.

In order to attract larger amounts of FDI in the future, Bulgaria and Serbia must implement attractive incentives, constantly improve the investment ambience and create attractive investment locations while providing a multitude of benefits for foreign investors. Therefore, rapid registration of business entities and minimal administrative activities at the opening and construction of buildings certainly leave a positive impression on the foreign investor and encourage them to continue with the initiated and engage in new projects. Campos and Kinoshita (2003) find that the host country institutions also influence investment decisions, because they directly affect business operating conditions. The cost of investment consists of not only the economic costs of investment, but also the non-economic costs, such as bribery and time lost in dealing with local authorities. According to Smarzynska Javoricik (2004) governments all over the world compete to attract FDI hoping that multinational corporations will bring new technologies, management skills and marketing know-how. In order to create an investment friendly environment, it is important to understand the factors that influence FDI inflows as well as the determinants of the composition of such flows. It is very welcome that, in addition to the said incentives, financial support for foreign investors is also provided, i.e., financial grants within various government programs are awarded. 


\section{REFERENCES}

[1] Aitken, B., Hanson, G., \& Harrison, A. (1997). Spillovers, Foreign Investment and Export Behavior. Journal of International Economics, 43(1-2), 103-132

[2] Alfaro, L., Chanda, A., Kalemli-Ozcan, S., \& Sayek, S. (2004). FDI and economic growth: the role of local financial markets. Journal of international economics, 64(1), 89-112.

[3] Asiedu, E. (2002). On the Determinants of Foreign Direct Investment to Developing Countries: Is Africa Different? World Development, 30(1), 107-119

[4] Barrell, R., \& Pain, N. (1999). Domestic institutions, agglomerations and foreign direct investment in Europe. European Economic Review, 43(4), 925-934

[5] Bénassy-Quéré, A., Fontagné, L., \& Lahrèche-Révil, A. (2001). Exchange-rate strategies in the competition for attracting foreign direct investment. Journal of the Japanese and international Economies, 15(2), 178-198.

[6] Bengoa, M., \& Sanchez-Robles, B. (2003). Foreign direct investment, economic freedom and growth: new evidence from Latin America. European journal of political economy, 19(3), 529-545.

[7] Bevan, A. A., \& Estrin, S. (2004). The determinants of foreign direct investment into European transition economies. Journal of comparative economics, 32(4), 775-787.

[8] Borensztein, E., De Gregorio, J., \& Lee, J. W. (1998). How does foreign direct investment affect economic growth?. Journal of international Economics, 45(1), 115-135.

[9] Branstetter, L. (2006). Is foreign direct investment a channel of knowledge spillovers? Evidence from Japan's FDI in the United States. Journal of International economics, 68(2), 325-344.

[10] Buch, C., \& Piazolo, D. (2001). Capital and trade flows in Europe and the impact of enlargement. Economic Systems, 25(3), 183-214

[11] Busse, M., \& Hefeker, C. (2007). Political risk, institutions and foreign direct investment. European journal of political economy, 23(2), 397-415.

[12] Campos, N. F., \& Kinoshita, Y. (2003). Why Does FDI Go Where It Goes? New Evidence from the Transition Economies. IMF Working Paper, No. 03/228

[13] Carstensen, K., \& Toubal, F. (2004). Foreign direct investment in Central and Eastern European countries: a dynamic panel analysis. Journal of comparative economics, 32(1), 3-22.

[14] Chen, C., Chang, L., \& Zhang, Y. (1995). The role of foreign direct investment in China's post-1978 economic development. World development, 23(4), 691-703

[15] Cheng, L. K., \& Kwan, Y. K. (2000). What are the determinants of the location of foreign direct investment? The Chinese experience. Journal of international economics, 51(2), 379-400.

[16] Ernst \& Young. (2013). Coping with the crisis - the European way. Ernst \& Young's Attractiveness Survey, Europe 2013, Retrieved from http://www.ey.com/Publication/vwLUAssets/ European-AttractivenessSurvey2013/\$FILE/ European-Attractiveness-Survey-2013.pdf

[17] Ernst \& Young. (2015). Comeback time. Ernst \& Young's Attractiveness Survey, Europe 2015, Retrieved from: http://www.eyeim.com/pdf/EY\%202015\%20European\%20attractiveness\%20survey.pdf

[18] Gastanaga, V., Nugent, J. B., \& Pashamova, B. (1998). Host Country Reforms and FDI Inflows: How Much Difference Do They Make? World Development. 26(7), 1299-1314

[19] Globerman, S., \& Shapiro, D. (2002). Global foreign direct investment flows: The role of governance infrastructure. World development, 30(11), 1899-1919.

[20] Grandov, Z., Mitić, B., \& Vojvodić, A. (2011). Foreign direct investment as exports incentive. TTEM-Technics Technologies Education Management, 6(4), 967-976

[21] Grigorova, V. (2007). FDI in Industry in Bulgaria. Sofia, Bulgarian Academy of Sciences

[22] Habib, M., \& Zurawicki, L. (2002). Corruption and foreign direct investment.Journal of international business studies, 33(2), 291-307.

[23] Hallward-Driemeier, M. (2003). Do Bilateral Investment Treaties Attract Foreign Direct Investment? A Bit ... and They Could Bite, Policy Research Working Paper, No.312

[24] Jensen, N. M. (2003). Democratic governance and multinational corporations: Political regimes and inflows of foreign direct investment, International Organization, 57(3), 587-616.

[25] Kaufmann, D., Kraay, A., \& Zoido-Lobatón, P. (1999). Governance Matters. Policy Research Working Paper, No. 2196

[26] Kragulj, D. (2003). Ekonomska kretanja i strane direktne investicije u zemljama u tranziciji. Management: Journal for Theory and Practice Management, 32(8), 19-27

[27] Kugler, M. (2006). Spillovers from foreign direct investment: within or between industries?. Journal of Development Economics, 80(2), 444-477. 
[28] Li, Q., \& Resnick, A. (2003). Reversal of fortunes: Democratic institutions and foreign direct investment inflows to developing countries. International organization, 57(1), 175-212.

[29] Markusen, J. R., \& Venables, A. J. (1999). Foreign direct investment as a catalyst for industrial development. European economic review, 43(2), 335-356.

[30] Noorbakhsh, F., Paloni, A., \& Youssef, A. (2001). Human capital and FDI inflows to developing countries: New empirical evidence. World development,29(9), 1593-1610.

[31] Penev, S. \& Marušić, A. (2011). Progress in transition and reform implementation in Serbia, comparing to other Western Balkan countries. Washington, International Finance Corporation

[32] Rodriguez-Clare, A. (1996). Multinationals, Linkages, and Economic Development. The American Economic Review, 86(4), 852-873

[33] Schneider, F., \& Frey, B. S. (1985). Economic and political determinants of foreign direct investment. World development, 13(2), 161-175.

[34] Slović, N. (2012). Poreski tretman i podsticaji za ulaganje u hartije od vrednosti u Srbiji. Pravno-ekonomski pogledi, III 1/2012

[35] Smarzynska Javorcik, B. (2004). The composition of foreign direct investment and protection of intellectual property rights: Evidence from transition economies. European economic review, 48(1), 39-62.

[36] Stein, E., \& and Daude, C. (2001). Institutions, Integration and the Location of Foreign Direct Investment. Washington DC, Inter-American Development Bank

[37] The International Trade Center. (2014). The Investment Map Database. Retrieved March 12, 2014, from http://www.investmentmap.org

[38] Vojinović Jaćimović, D. (2002). The direct investment decision process. Management: Journal for Theory and Practice Management, 26(7), 48-53

[39] Yin-Li Tun, W.N.W. Azman-Saini \& Siong-Hook Law. (2012). International Evidence on the link between Foreign Direct Investment and Institutional Quality. Inzinerine Ekonomika-Engineering Economics, 23(4), 379-386

[40] Zeković, S. (2002). Foreign investments and environmental protection in FRY. Management: Journal for Theory and Practice Management, 27(7), 25-29

Receieved: October 2014. Accepted: November 2015.

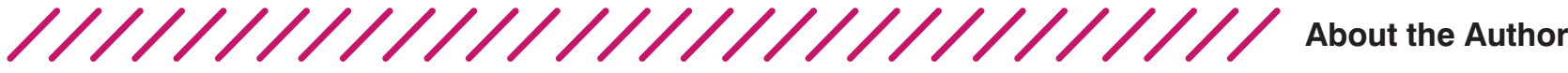

\section{Biljana Stankov \\ Higher School of Professional Business Studies in Novi Sad, Serbia}

Biljana Stankov is an MSc holder in Economics employed as teaching assistant at Higher School of Professional Business Studies in Novi Sad. During many years of working in higher education, first as an associate and then a teaching assistant, she dealt with various subjects in the field of economics. She completed undergraduate academic studies and masters studies in the field of marketing management and

European economy. Currently she is a final year student of doctoral studies at the Faculty of Economics and Engineering Management in Novi Sad, University Business Academy at the Business Economics study program. She participated in many international scientific conferences and has published several papers in scientific journals. The key fields of her interest and future development are foreign direct investments, competitiveness, international and European economy.

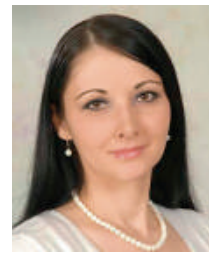




\section{Jasmina Markov \\ Faculty of Economics in Subotica, Serbia}

Jasmina Markov completed undergraduate studies at the Faculty of Economics in Subotica, Department of Novi Sad, where she completed her masters studies as well. Her fields of interest during these studies were marketing and trade. In the year of 2010 she started her doctoral studies at the same Faculty, in the Management and Business study program, Marketing module. From 2008 to 2013 she worked at the Higher School of Professional Business Studies in Novi Sad, as an assistant - master in the specialized field of Business Economics and Management. In addition, she spent a year volunteering in the Government of the Autonomous Province of Vojvodina in the Province Secretariat for Education and Culture. She has also published several papers in scientific journals and has participated in numerous international conferences.

Ivana Milošević Faculty of Economics and Engineering Management in Novi Sad, Serbia

Ivana Milošević graduated in 2009, at the Faculty of Economics in Novi Sad, GPA 8.80, and completed her masters studies in 2013, GPA 9.67, at the Faculty of Agriculture in Novi Sad. She commenced her PhD studies in 2013, at the Faculty of Economics and Engineering Management in Novi Sad - University Business Academy in Novi Sad (program of study: Business Economics). She is engaged at the same Faculty as an assistant in the following subjects: Macroeconomics, National Economy and

Public Finance and has also participated in the process of accreditation and selfevaluation of the Faculty. She is engaged in the program of continuous professional development of teachers, educators, experts and directors for 2014/2015 and 2015/2016 school years under the auspices of ZUOV (Ministry of Education, Science and Technological Development).
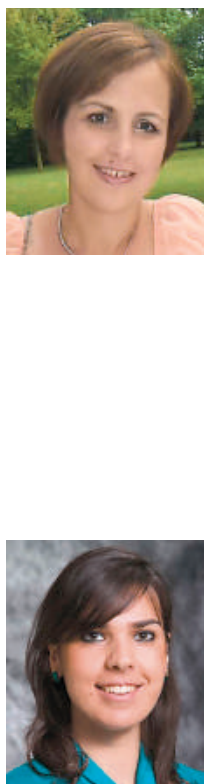